Acta Manilana 64 (2016), pp. 75-86

Printed in the Philippines

ISSN: 0065-1370

\title{
Reviving the Philippine shrimp industry: molecular diagnostics and therapeutics
}

\author{
Maria Violeta R. Tare ${ }^{1,2,3}$, Pocholo Mari T. Arabit1,2, Mark Anthony G. Fran ${ }^{3}$, \\ David Angelo V. Guanzon ${ }^{1,2}$, Jalizah Jaira E. Lim ${ }^{1,2}$, Sharlaine Joi Ann B. Orense ${ }^{1,2}$, \\ Joselito A. Tabardillo Jr. ${ }^{3}, \mathcal{E}$ Mary Beth B. Maningas ${ }^{* 1,2,3}$
}

${ }^{1}$ Graduate School; ${ }^{2}$ Department of Biological Science, College of Science; ${ }^{3}$ Research Center for the Natural and Applied Sciences, University of Santo Tomas, 1015 Manila, Philippines

In 1994, the Philippines was one of the top three producers in shrimp aquaculture, reaching a peak of 91MT. However, diseases caused a rapid decline in shrimp production, down to less than 50MT in 1997, and the Philippine status in shrimp aquaculture production has dwindled to the $13^{\text {th }}$ spot. Production has not yet recovered and stabilized, as these diseases still plague the industry up to this day. The strict implementation of importation laws for broodstock and better management practices helped the industry to make up for losses, and is now starting to revive. The scientific community is doing its part to hasten this process, shrimp research is of consistent interest to several research institutions providing deeper understanding regarding viral and bacterial diseases and their interactions with the host. However, the challenge remains as to how research can be translated and applied in the field, to provide the shrimp industry with science-based management strategies. This review provides a balance of both basic and applied research with the ultimate goal of reaching out to the industry through useful and beneficial knowledge together with simpler and costeffective detection methods and alternative, effective immunostimulants.

Keywords: shrimp biotechnology, shrimp immunity, molecular detection

\section{INTRODUCTION}

Marine and freshwater shellfish, including shrimps, are a key source of protein in a continuously growing population. The increased consumption of shrimps and the limited supply from capture fisheries have led to a demand for farmed shrimps and an expansion of the shrimp industry in the Philippines. Due to the demand for high-value seafood products,

*To whom correspondence should be addressed marybethmaningas@gmail.com the industry has generated profits, foreign exchange earnings and an important source of livelihood. However, the expansion of the shrimp industry was accompanied by an increased incidence of economically significant diseases, particularly of viral and bacterial origin [1, 2].

Among the viruses affecting farmed shrimps in the Philippines are the white spot syndrome virus (WSSV), the taura syndrome virus (TSV) and the Laem-Singh virus (LSNV). WSSV has been used for challenge tests due to its devastating impact in shrimp populations upon 
infection, whereas TSV and LSNV have been detected in the country for the first time. The clinical signs, transmission, distribution and incidence of diseases due to these viral pathogens have been reviewed by AndrinoFelarca et al. [3]

Bacterial agents from the genus Vibrio have also caused significant morbidity and mortality in shrimps in the Philippines. The major species causing Vibriosis are $V$. harveyi, $V$. fluvialis, $V$. parahaemolyticus, $V$. damsel, and $V$. vulnificus [4]. It is worth noting that a toxic plasmid of $V$. parahaemolyticus has been found to be the causative agent for an emerging disease in shrimp, acute hepatopancreatic degenerative necrotic disease (AHPND) or commonly known as early mortality syndrome (EMS) due to mass mortality of infected shrimp within days of stocking [5].

These pathogens have posed a significant threat to the shrimp industry, causing millions of dollars of losses in production. The detection, control and prevention of shrimp diseases caused by these pathogenic agents are essential in supporting the ailing shrimp farming industry. Efficient detection methods have been provided by molecular diagnostics technology, and contribute significantly to the mitigation of production losses. A therapeutic tool for the management of shrimp diseases is gene silencing, which is based on the elucidation of the interaction between the shrimp and the viral agents. Immunostimulants have provided an effective means for increasing immunocompetency and disease resistance in shrimps, and have been widely accepted by the shrimp culture industry $[6,7]$.

This review paper intends to provide an insight and understanding of several aspects of shrimp research. It covers loop-mediated isothermal amplification (LAMP)-based and polymerase chain reaction (PCR)-based detection of shrimp diseases, the utilization of RNA interference for the elucidation of gene function in relation to WSSV infection and the use of immunostimulants for shrimps.

\section{DETECTION OF SHRIMP PATHOGENS}

Viral and bacterial pathogens are the most common causes of the shrimp diseases, accounting for $60 \%$ of the economic losses in aquaculture for viral diseases and $20 \%$ for bacterial infections [8]. Early detection and constant surveillance of these pathogens remain to be one of the most effective countermeasures against shrimp diseases because it provides ample time for officials to make breakeven strategies and proper aquaculture practices to mitigate production losses [9]. Because of their economic importance, rapid and simple diagnostics for the WSSV, TSV, LSNV, and species of Vibrio were developed and are reviewed in this paper.

Polymerase chain reaction-based methods. In recent years, molecular detection has become the most widely accepted technique in disease diagnosis because it is faster and more accurate than the traditional procedures [10]. Among these, PCR detection and its derivatives are the most reliable in detecting aquaculture pathogens [9].

White spot disease, caused by WSSV, remains to be one of the most serious viral disease, due to its high mortality rate that can take place 310 days after post-infection [11]. Infected shrimps exhibit loss of appetite, lethargy and the characteristic white spots located on the carapace from calcified deposits, symptoms that eventually lead to mass mortality [12]. The virus is viable to a wide range of economicallyimportant shrimp species in the Philippines, Peneaus monodon [13], Peneaus vannamei [14], and Macrobrachium rosenbergii [15].

In 2011, WSSV was detected from P. monodon samples in Bulacan [13]. The authors also 
reported that incidental shrimps such as Metapenaeus dalli all tested negative in onestep and nested PCR, a possible display of resistance to the virus. On the same year, a partial sequence of the WSSV isolate from the Philippines was generated [14] and was subsequently used to design PCR primers. PCR detection of the disease using the designed primers showed a low incidence rate of $15 \%$ for $P$. vannamei. Continued surveillance of WSSV from June 2014 to July 2015 for both P. monodon and $P$. vannamei was conducted in other sites in the Philippines and showed a higher total prevalence rate of $25 \%$ [unpublished data].

The successful detection of WSSV indicated that other shrimp pathogens may be present but are left undetected and unreported in the country, which may result to the rapid spread of diseases. To prevent this, LSNV became the target for possible detection. Initial screening studies for the RNA-based virus, which causes Monodon slow growth syndrome (MSGS), was conducted between the years 1998-2007. The studies revealed that there have been no carriers of the disease in the country [16].

However, a recent study [unpublished data] showed the presence of LSNV in P. monodon samples from the province of Bulacan. Detection was done by observing the external symptoms of the sampled shrimps. LSNV was further detected in the shrimp samples via PCR amplification, and the sequenced the target gene exhibited a 99\% homology to LSNV.

Another RNA-based virus, TSV, was also detected in shrimp farms across the country. TSV is capable of causing significant mortalities in reared P. vannamei three days after the onset of disease [17] and was also previously unreported in the country. In 2014 [unpublished data], TSV was detected via PCR and the resulting sequences indicated close homology to the TSV Taiwan isolate.
Aside from viral pathogens, bacteria are also major causes of mortalities in shrimp ponds. Vibriosis is a common example, caused by several species of Vibrio such as V. alginolyticus [18], V. anguillarum [19], V. harveyi [20], V. vulfinicus [20], and V. parahaemolyticus [21], among others. Initial efforts for the rapid detection of species of Vibrio were done using PCR and microbiological methods [22]. A virulent strain of $V$. parahaemolyticus was associated with an emerging disease that causes massive mortalities around Southeast Asia and Mexico called acute hepatopancreatic necrosis disease (AHPND) [23]. The disease creates lesions in the hepatopancreas in shrimp when the $V$. parahaemolyticus plasmid with the toxin gene was present in the species [5]. In 2015, the presence of the virulent strain of $V$. parahaemolyticus was first recorded from across the country and confirmed by PCR amplification and histopathology, together with microbiological and biochemical techniques. Alarmingly, the prevalence of AHPND was found to be $24 \%$ in the Philippines [24].

Early detection is important for the mitigation and the control of the spread of these diseases. But it remains to be a problem for local shrimp farms especially for those located far from accredited testing laboratories and do not have the capital to invest in self-test detection kits. The delay in action from time lost in transportation and testing of samples can greatly reduce shrimp harvest when diseases are present. It is also expensive because PCRbased assays require expensive reagents, specialized equipment and technical personnel to perform. It is of utmost importance that the diagnosis be rapid, reliable, and can be done on-site.

Loop-mediated isothermal amplification. A novel and emerging technology called LAMP [25] was used as the platform for the developed diagnostic kit for WSSV. LAMP gained popularity in the detection of several pathogens 
for the aquaculture sector such as Edwardsiella tarda in Japanese flounder [26], fish iridovirus [27], TSV [28] and WSSV [29]. The LAMP reaction uses a specialized polymerase, the Bst polymerase which has a strand displacement activity, and four sets of primers that target six specific regions in the gene of interest, making LAMP more specific and sensitive to the target sequence. The amplification proceeds in isothermal conditions for one hour. The visualization of the result is straightforward and can be performed by the naked eye. The simplicity and rapidity of LAMP makes it desirable as a diagnostic platform for farm applications.

Four sets of primers (patented) highly specific for the Philippine WSSV isolates were developed [30]. The different sets of primers were tested, and the most consistent and sensitive was used for the diagnostic kit. The designed primers were further optimized [22], and compared to the conventional PCR for its analytical sensitivity and specificity.

Utilizing the optimized LAMP assay, a prevalence rate of $48 \%$ for WSSV from selected sites in the Philippines was recorded. Additionally, the assay provided faster and ten times more sensitive results than PCR. It was also noted that the formation of LAMP products is possible at temperatures lower than $60^{\circ} \mathrm{C}$, and the incubation period can be reduced to $45 \mathrm{~min}$ with consistent results.

Despite the improvements made for the LAMP protocol, the DNA extraction remains to be time consuming and costly. To resolve this difficulty, our group formulated and developed a rapid, simple and cost-effective diagnostic kit that can used for shrimp farm monitoring of WSSV. The developed diagnostic kit includes a simple DNA extraction kit and protocol (patent pending), LAMP premix buffers and a fabricated heat block tailor-made for LAMP applications. Using the developed diagnostic kit, WSSV was tested across the Philippines. A prevalence rate of 88\% was observed in Luzon, 63\% in Visayas and 65\% in Mindanao [unpublished data].

The alarming number of pathogens present in our country remains to be a constant threat to the Philippine shrimp industry. A summary of the pathogens detected in the Philippines is presented in Table 1, and the areas covered by the pathogens are shown in Fig.1, together with their annual prevalence during the period of 2010-2016. Developing rapid and farm-ready diagnostic kits for these pathogens are essential in aiding the industry and the government in shrimp health management. Early detection and rapid diagnosis of the disease is only the first step in creating a sustainable and productive aquaculture industry, its breakthroughs will go a long way for the mitigation and prevention of diseases, as well as understanding the nature of the relationship of the pathogen to its host. In the future lies a rapid, simple and costeffective diagnostic platform that can be used by farm and hatchery operators for timely and accurate on-site detection of pathogens.

\section{GENE SILENCING THERAPY}

The development of strategies for the prevention of shrimp disease outbreak could be facilitated by an understanding of host-virus interactions. The suppression of gene expression based on sequence homology between the dsRNA trigger and the target gene comprises RNAi together with a set of related cellular processes. It is an approach with incredible potential for therapeutic purposes, using dsRNA that targets viral sequences or homologous viral sequences in vivo [31]. RNAi applications for shrimp diseases has been reviewed by Maningas and Tare [32], and the review is supplemental to the current paper. From the functional analysis of transglutaminase (TGase) and clotting protein (CP) in the shrimp clotting system using gene silencing as the determining assay for the role of the two genes 
Reviving the Philippine shrimp industry: molecular diagnostics and therapeutics

Table 1. Pathogens of Interest Detected in Shrimp Via Molecular Diagnostics

\begin{tabular}{|c|c|c|c|c|}
\hline Pathogen & $\begin{array}{c}\text { Infected shrimp } \\
\text { species }\end{array}$ & \begin{tabular}{|c|}
$\begin{array}{c}\text { Molecular detection } \\
\text { platform }\end{array}$ \\
\end{tabular} & $\begin{array}{l}\text { Sampling sites in the } \\
\text { Philippines }\end{array}$ & Reference \\
\hline \multicolumn{5}{|c|}{ Bacterial } \\
\hline Vibrio spp. & P. vannamei & PCR and LAMP & Pangasinan & Nicolasora et al. (2014) \\
\hline $\begin{array}{l}\text { Vibrio } \\
\text { parahaemolyticus } \\
\text { causing Acute } \\
\text { Hepatopancreatic } \\
\text { Necrosis Disease } \\
\end{array}$ & P. vannamei & PCR & $\begin{array}{c}\text { Bataan, Bulacan, } \\
\text { Pampanga, Cebu, Bohol, } \\
\text { General Santos, Saranggani }\end{array}$ & Dabu et al. (2015) \\
\hline \multicolumn{5}{|c|}{ Viruses } \\
\hline \multirow{5}{*}{ WSSV } & P. monodon & PCR and Nested PCR & Bulacan & $\begin{array}{c}\text { Alenton and Maningas } \\
\text { (2011) }\end{array}$ \\
\hline & P. vannamei & PCR & \begin{tabular}{|c|}
$\begin{array}{c}\text { Batangas, Zambales, Capiz } \\
\text { and General Santos city }\end{array}$ \\
\end{tabular} & Maralit et al. (2011) \\
\hline & P. vannamei & LAMP & $\begin{array}{c}\text { Batangas, Zambales, Capiz } \\
\text { and General Santos city }\end{array}$ & Maralit et al. (2012) \\
\hline & P. vannamei & PCR and LAMP & $\begin{array}{c}\text { Bulacan, Batangas, Laoag, } \\
\text { Iloilo, andLeyte }\end{array}$ & Nicolasora et al. (2014) \\
\hline & $\begin{array}{l}\text { P. monodon and } \\
\text { P.vannamei }\end{array}$ & PCR and LAMP & $\begin{array}{c}\text { Bulacan, Bataan, Cebu, } \\
\text { Davao and General Santos } \\
\text { city }\end{array}$ & (Unpublished) \\
\hline TSV & P. vannamei & PCR & $\begin{array}{c}\text { Bulacan, Batangas, Bohol } \\
\text { and Cebu }\end{array}$ & (Unpublished) \\
\hline LSNV & P. monodon & PCR & \begin{tabular}{|c|} 
Bulacan, Batangas, \\
Pangasinan and Pampanga \\
\end{tabular} & (Unpublished) \\
\hline
\end{tabular}

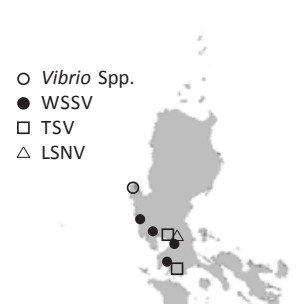

A

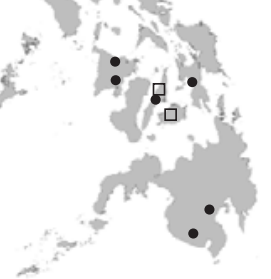

Figure 1. (A) Detected shrimp pathogen distribution in the Philippines; (B) Prevalence of shrimp pathogens per year.

[33] to the proposed molecular mechanism of the shrimp clotting system [34], succeeding studies followed a trend of uncovering hostvirus interactions towards understanding and harnessing these relationships for the prevention of disease outbreak [35].

WSSV-shrimp homologs were found to be involved in viral infectivity in kuruma shrimp, Marsupenaeus japonicus [36]. This finding was instrumental in several studies discussed in this review, reporting the discovered contigs involved in WSSV infection in the freshwater shrimp, Macrobrachium rosenbergii and the black tiger prawn, Penaeus monodon.

Immune defense responses are affected upon invasion of WSSV, as shown by the characterization of hemocyanin-like subunits of $M$. rosenbergii, initially known as contigs 13 and 37. Both genes were found to be upregulated during the early stages of WSSV infection [37].

Contig 23 is one of the most promising candidates for therapeutic development for 
having rendered $100 \%$ survival rate at seven days post-infection when injected with c23dsRNA and infected with WSSV, signifying its interaction with the virus for rendering its protective effect upon silencing both in $M$. rosenbergii and $P$. monodon [38]. The rest of the contigs, 20, 31 and 34 were found to be involved in the shrimp's metabolic processes, which also responds to viral activity and triggers host responses upon infection [our unpublished data]. In addition to host genes, the knockdown of a viral gene VP9 has significantly increased shrimp survival even upon re-infection and is suspected to play a key role in viral replication [39].

A transcriptome database of genes from tiger shrimp that survived WSSV challenged was generated by Maralit [40], who also unveiled a ubiquitin conjugating enzyme-like gene that renders protective effect to WSSV challenged M. rosenbergii [unpublished data]. Table 2 summarizes the genes utilized by RNA interference discussed in this review.

An exciting platform has been provided by the gene silencing technology by showing the effect of knocking down a target gene on the organism. Interests on its application in shrimp is at a steady rate, Fig. 2 summarizes the authors intention to continuously join this effort, with the main goal of identifying genes suitable for

Table 2. Target Genes Used in RNAi Studies Discussed in This Review

\begin{tabular}{l|c|c}
\hline \multicolumn{1}{c|}{ Target Gene } & Source & Reference \\
\hline $\begin{array}{l}\text { Hemocyanin-like } \\
\text { subunits }\end{array}$ & Host & Tare et al. (2015) \\
\hline Contig 20 & Host & Unpublished \\
\hline Contig 23 & Host & Unpublished \\
\hline Contig 31 & Host & Unpublished \\
\hline Contig 34 & Host & Unpublished \\
\hline $\begin{array}{l}\text { Ubiquitin } \\
\text { conjugating enzyme- } \\
\text { like gene }\end{array}$ & Host & Unpublished \\
\hline VP9 & Viral & Alenton et al. (2016) \\
\hline
\end{tabular}

protecting the shrimps against infection thereby stabilizing shrimp production.

\section{IMMUNOSTIMULATION FOR DISEASE RESISTANCE}

Another approach that our group has adopted towards the prevention of shrimp pathogenesis is based on the natural process of immunostimulation. Immunostimulation is the introduction of molecules into the system of an organism with the intention of improving its response against infection from pathogenic causes [41-43]. An update on the use of immunostimulants in the Philippines has been published [44]. Thus, the coverage of this review focuses on the multiple studies engrossed on immunostimulation and done at the aforementioned laboratory; all these exploring the potential of recycled natural products and bacterial species found in shrimp gut (our unpublished data) as immunostimulants (Table 3).

Natural immunostimulants are safe for the environment and cost-effective. In addition, these can be sourced from bacteria, plant products, such as herbs and fruits, and even animal scraps, such as shells [42, 45-47]. What marks these products as viable candidates for immunostimulants is the throng of minerals and

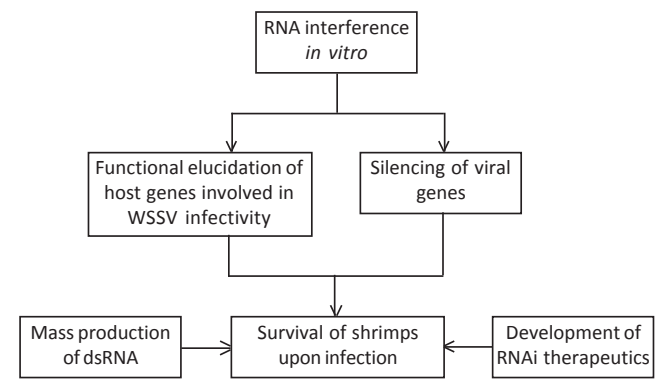

Figure 2. The conceptual framework of RNAi studies starting from in vitro production of dsRNA, the goal is to develop a more efficient, costeffective, mass production of dsRNA and the eventual development of RNAi therapeutics for application in the field. 
compounds stored within their varying components. Waste plant products provide rich sources of metabolites such as carbohydrates, proteins and mineral constituents. It is also abundant in phytochemicals such as flavonoids, alkaloids, tannins and saponins which act as antioxidant and defense mechanism against free radicals that can cause debilitating disease in shrimps [48].

Several natural products derived from plant, algae, animal and bacterial sources have been explored in our laboratory for their immunostimulation potential (Table 3). To make use of the specific compounds, the raw materials were either subjected to further extraction, through either aqueous or ethanolic solutions $[15,49,50]$, or introduced in their crude powdered forms $[18,51,52]$. Extracted treatments were more widely used since the crude extracts are comprised of more purified compounds such as phenols, tannins and flavonoids [48].

Herbal medicine like Cyanodon dactylon, Aegle marmelos, Tinospora cordifolia, Picrorhiza kurooa, and Eclipta resulted to better performance in the haematological, biochemical and immunological parameters from the immunostimulant-incorporated diet fed to WSSV-challenged P. monodon [49]. Mangifera indica crude extract and powdered treatments against WSSV was found to yield $80 \%$ survival rates and elevated immune parameter values [our unpublished data]. Mangifera indica kernels have been used as immunostimulant for Penaeus indicus against WSSV [53]. Ethanolic and hotwater extracts from algae, (Fucus, Laminaria, and Gracilaria) exhibited antiviral activity and aided in the prevention of the attachment of the virus to host cells $[54,55]$. Aside from algae, fruit berries also exhibit possible immunomodulatory properties. A crude ethanolic extract of a species of raspberry Rubus coreanus exhibited significantly increased immunity and expression of antioxidant enzyme activities in P. vannamei after challenged with Vibrio alginolyticus [56].

The method of administering immunostimulants to the shrimps revolve around three methods: feeding, immersion and injection. Of all the three methods, injection is the most invasive and has been devised in a study involving agarcarotenoid complex [unpublished data], chitin and chitosan [57], hot-water extract of Gelidium amansi, [58] and hot-water extract of $S$. duplicatum [59]. Apart from injection, introduction through feeding was also employed for eregosan [47], Sargassum fusiforme [60] and

Table 3. A Summary of the Immunomodulatory Studies Done by the Authors in This Paper

\begin{tabular}{l|c|c|c|c|c}
\hline \multicolumn{1}{c|}{ Source } & Components & $\begin{array}{c}\text { Extraction } \\
\text { Method }\end{array}$ & $\begin{array}{c}\text { Method of } \\
\text { Introduction }\end{array}$ & Pathogen & Reference \\
\hline \multicolumn{7}{c}{ Plant Products } \\
\hline Citrus microcarpa & Vitamin C & Ethanol & Feeding & V. alginolyticus & Unpublished \\
\hline Curcuma longa & Curcumin & Powdered & Feeding & V. alginolyticus & Alambra et al. (2012) \\
\hline Mangifera indica & Mangiferin & Powdered & Feeding & WSSV & Unpublished \\
\hline Mangifera indica & Mangiferin & Ethanol & Feeding & WSSV & Unpublished \\
\hline Musa paradisiaca & Polyphenols & Powdered & Feeding & V. alginolyticus & Unpublished \\
\hline \multicolumn{7}{|c|}{ Marine Algae } \\
\hline Gracilaria edulis & Betaglucan & Aqueous & Immersion & V. alginolyticus & Maningas et al. (2013) \\
\hline Gracilaria edulis & Betaglucan & Aqueous & Immersion & WSSV & Unpublished \\
\hline Sargassum polycystum & Fucoidan & Ethanol & Feeding & WSSV & Arizo et al. (2015) \\
\hline \multicolumn{7}{|c|}{ Animal Sources } \\
\hline Shrimp Shells & Carotenoids & TOSS & Injection & V. alginolyticus & Unpublished \\
\hline \multicolumn{7}{|c|}{}
\end{tabular}


on fucoidan [61]. Immersion strategies have also been devised and utilized [50, 58]. Between feeding and immersion, the former is more widely employed since it required a smaller amount of extracted compounds [50, 59, 62, our unpublished data], as little as $500 \mathrm{mg}$ of an extract was enough to fuel the whole study $[63,49,15$, our unpublished data]. As far as efficacy and complexity is concerned, all three treatment strategies generate lessened mortalities and higher immune parameter values; however, feeding is the simplest mode of administration due to the minimal volume of extracts required and the hassle-free preparation of experimental treatments [58, our unpublished data].

Compounds of immunostimulatory functions are often exploited for their antioxidant properties or their structural similarity to pathogenic components [46, 64]. Compounds with molecular structure similar to that of pathogens are termed as pathogen-associated molecular patterns (PAMPs), and are rooted to play a crucial role in the activation of the key enzymatic reaction of the crustacean immune system, such as the proPhenoloxidase (PO) system [65]. The use of PAMPs tend to produce inverse correlation between survival and compound concentrations [our unpublished data, 15]. Higher treatment concentrations cause an increase in free radical production that induce irreversible damage to both host and foreign cells and lead to weaker survival rates despite the increased immune parameter values. Similarly, since more PO reactions are produced, an exhaustion of the immune system can be observed as indicated by the drop in immune parameter values [68].

Antioxidants have also been employed as an immunostimulant [our unpublished data, 49, 53]. Antioxidant key compounds are expected to promote increased survivability, heightened hemocyte count and increased superoxide dismutase levels. This can be related to the damage prevention to host cells, since the enzyme reactions produced by the humoral immune response tend to release free radicals that destroy foreign cells [67].

Aside from conferring protection against infection, growth was also found to be affected by the administration of immunostimulants. Crude fucoidan was able to increase the weekly weight gain of shrimp [15, 68]. Modified feeds enhanced the feed utilization and the growth performance of treated shrimps [69-71]. In summary, materials containing these compounds prove to aid in improving the shrimp growth performance and immune response against pathogens through their effective actions in regulating enzyme reactions (Fig. 3).

Developing immunomodulatory feed additives from scrap materials paves way to providing cost-effective substitutes for commercial immunostimulants such as Macroguard ${ }^{\mathrm{TM}}$. A U.S. patent 6440466 has been granted to the composite of plant extracts of Lantena camera, Aegle marmelos, Ocimum sanctum, Mimosa pudica, Cynodon dactylon, Curcuma longa, and Allium sativum which was found useful as prophylactic and therapeutic agents against viral (WSSV) and bacterial disease [72].

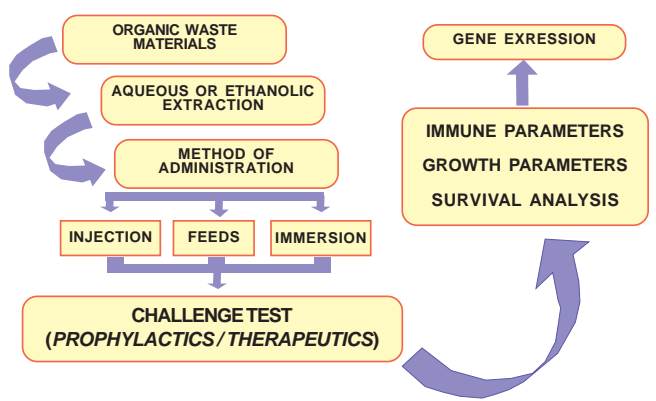

Figure 3. Immunostimulation experiments begin with the treatment preparation from organic materials and continue on to the challenge experiments wherein immune parameters, growth rate, survival analysis and even gene expression is evaluated. 
Despite the advances made in the use of immunostimulants, the immune mechanism of crustaceans against viruses is yet to be defined, and more efficient natural therapeutic strategies can be developed. Endemic Philippine fruits and plants can be explored for possible efficacy as bactericidal and antiviral treatments.

\section{CONCLUSION}

The emergence of pathogens has yet to cease and thus, the struggle to develop mitigation techniques to hamper economic loss and promote shrimp production is a persistent challenge worth pursuing. The development of molecular diagnostics, RNAi technology and immunostimulants play a vital and significant role in improving shrimp health management and practices, and in reducing losses in the shrimp farming industry.

\section{ACKNOWLEDGMENT}

Our research work was supported by grants from the Commission on Higher Education-Higher Education Research Network (CHED-PHERNet) and the Department of Science and TechnologyPhilippine Council for Agriculture, Aquatic and Natural Resources Research and Development (DOST-PCAARRD).

\section{REFERENCES}

[1] Hauton C. The scope of the crustacean immune system for disease control. Journal of Invertebrate Pathology 2012; 110:251-260.

[2] Muegue M, Caipang, \& Geduspan J. Current status of shrimp aquaculture in the Philippines. Biotechnological advances in shrimp health management in the Philippines. (Kerala, India: Research signpost, 2015). ISBN: 978-81-3080558-0.

[3] Andrino-Felarca K, Estante E, \& Lazado C. Viral diseases of shrimp in the Philippines. Biotechnological advances in shrimp health management in the Philippines. (Kerala, India: Research signpost, 2015). ISBN: 978-81-3080558-0.
[4] Manilal A, Selvin J, \& George S. In vivo therapeutic potentiality of red seaweed, Asparagopsis (Bonnemaisoniales. Rhodophyta) in the treatment of Vibriosis in Penaeus monodon. Saudi Journal of Biological Sciences 2012; 19:165-175.

[5] Tran L, Nunan L, Redman R, Mohney R, Pantoja L, Fitzsimmons C, Kevin \& Lightner D. Determination of the infectious nature of the agent of acute hepatopancreatic necrosis syndrome affecting penaeid shrimp. Diseases of Aquatic Organisms 2013; 105:45-55.

[6] Pholdaeng K \& Pangsamart S. Studies on the immunomodulatory effect of polysaccharide gel extracted from Durio zibethinus in Penaeus monodon shrimp against Vibrio harveyi and WSSV. Fish \& Shellfish Immunology 2010; 28:555-561.

[7] Hsieh T, Wang J, Li C, Kuo C, \& Hsieh S. Effects of Rutin from Toona sinensis on the immune and physiological responses of white shrimp (Litopenaeus vannamei) under Vibrio alginolyticus challenge. Fish \& Shellfish Immunology 2008; 25:581-588.

[8] Flegel T. Historic emergence, impact and current status of shrimp pathogens in Asia. Journal of Invertebrate Pathology 2012:166-173.

[9] Caipang C. Utilization of loop-mediated isothermal amplification (LAMP) for the detection of pathogens in shrimp and fish aquaculture in the Philippines. In Caipang MM, CMA Biotechnological advances in shrimp health managament in the Philippines, pp. 149-163. (Kerala, India: Research Signpost, 2015).

[10] Biswas G \& SM. Loop-mediated isothermal amplification (LAMP) assays for detection and identification of aquaculture pathogens: current state and perspectives. Applied Microbiology \& Biotechnology 2014.

[11] Lightner D. Handbook of Shrimp Pathology and Diagnostic Procedures for Diseases of Penaeid Shrimp. (Baton Rouge: World Aquaculture Society, 1996).

[12] Pradeep B. Biology, Host Range, Pathogenesis and Diagnosis of White spot syndrome virus. Indian Journal of Virology 2012.

[13] Alenton R \& Maningas MBB. Detection of white spot syndrome virus on Penaeus monodon and Metapenaeus dali From Bulacan, Philippines. Acta Manilana 2011. 
Tare MVR, et al. | Acta Manilana 64 (2016)

[14] Maralit B, C. PCR detection of white spot syndrome virus (WSSV) from farmed Pacific white shrimp, (Litopeneaus vannamei) in selected sites of the Philippines. Agriculture, Aquarium, Conservation and LegislationInternational Journal of the Bioflux Society 2011; 474-480.

[15] Arizo M, S.E. Crude fucoidan from Sargassum polycystum stimulates growth and immune response of Macrobrachium roserbergii against white spot syndrome virus (WSSV). Aquaculture, Aquarium, Conservation and Legislation - International Journal of the Bioflux Society 2015; 535-543.

[16] Sittidilokratna N. Detection of Laem-Singh virus in cultured Penaeus monodon from several sites in the Indo-Pacific region. Diseases of Aquatic Organisms 2009; 195-200.

[17] Yu C, A.S. Outbreaks of Taura syndrome in Pacific white shrimp Penaeus vannamei cultured in Taiwan. Fish Pathology 2000; 35:21-24.

[18] Alambra J \& Maningas M. Immunomodulatory effects of turmeric, Cucurma longa (Magnoliophyta, Zingiberaceae) on Macrobrachium rosenbergii (Crustacea, Palaemonidae) against Vibrio alginolyticus (Proteobacteria, Vibrionaceae). AACL Bioflux 2012.

[19] Pridgeon J. Major bacterial diseases in aquaculture and their vaccine development. Animal Science Reviews 2012; 141.

[20] Alday-Sanz V. Clearing mechanisms of Vibrio vulfinicus biotype I in Black Tiger Shrimp Peneaus monodon. Diseases of Aquatic Organisms 2002; 91-99.

[21] Soto-Rodriguez S. Field and experimental evidence of Vibrio parahaemolyticus as the causative agent of acute hepatopancreatic necrosis disease of cultured shrimp (Litopenaeus vannamei) in Northwestern Mexico. Applied and Environmental Microbiology 2015; 1689-1699.

[22] Nicolasora A, Maralit B, Caipang C, Calpe A, \& Maningas M. Utilization of loop-mediated isothermal amplification (LAMP) technology for detection fo White spot syndrome virus (WSSV) and Vibrio spp. in Litopenaeus vannamei in selected sites in the Philippines. Philippine Science Letters 2014; 7(2):308-316.

[23] Lightner D. Early mortality syndrome affects shrimp in Asia. Global Aquaculture Alliance Advocate 2012; 40.
[24] Dabu I, Lim JJ, Arabit PM, Orense SJ, Tabardillo JA, Corre VL, \& Maningas MBB. First report of acute hepatopancreatic necrosis disease in the Philippines. Aquaculture Research 2015; 1-8. doi: 10.1111/are12923.

[25] Notomi T, Okayama H, Masubuchi H, Yokenawa T, Watanabe K, Amino N, \& Hase T. Loop-mediated isothermal amplification of DNA. Nucleic Acids Research 2000; 28(12).

[26] Savan R. Sensitive and rapid detection of edwardsiellosis in fish by loop-mediated isothermal amplification method. Applied and Environmental Microbiology 2004; 70:621—624.

[27] Caipang C. Rapid detection of fish iridovirus using loop-mediated isothermal amplification (LAMP). Journal of Virological Methods 2004; 121:155161.

[28] Kiatpathomchai W. Shrimp taura syndrome virus detection by reverse transcription loop-mediated isothermal amplification combined with lateral flow dipstick. Journal of Virological Methods 2007; 153:214-217.

[29] Kono T. Detection of white dpot syndrome virus in shrimp by loop-mediated isothermal amplification. Journal of Virological Methods 2004; 115:59-65.

[30] Maralit B, C.C. Development of primers for loopmediated isothermal amplification of Philippine white spot syndrome virus isolates. AACL Bioflux 2012.

[31] Robalino J, Bartlett T, Shepard E, Prior S, Jaramillo G, Scura E, Chapman R, Gross P, Browdy C, \& Warr G. Double-stranded RNA induces sequence-specific antiviral silencing in addition to nonspecific immunity in a marine shrimp in the invertebrate antiviral response. Journal of Virology 2005; 79:13561-13571.

[32] Maningas $M$ \& Tare M. RNAi technology application for cultured shrimp. Biotechnological advances in shrimp health management in the Philippines. (Kerala, India: Research Signpost, 2015). ISBN: 978-81-308-0558-0

[33] Maningas M, Kondo H, Hirono I, Saito-Taki T, \& Aoki T. Essential function of transglutaminase and clotting protein in shrimp immunity. Molecular Immunology 2008; 45:1269-1275.

[34] Maningas $M$, Kondo $H$, \& Hirono I. Molecular mechanisms of the shrimp clotting system. Fish \& Shellfish Immunology 2013; 34:968-972. 
Reviving the Philippine shrimp industry: molecular diagnostics and therapeutics

[35] Vatanavicharn T, Prapavorarat A, Jaree $P$, Somboonwiwat K, \& Tassanakajon A. PmVRP15, a novel viral responsive protein from the black tiger shrimp, Penaeus monodon, promoted white spot syndrome virus replication. PLos One 2014; $9(3)$.

[36] Dang L, Koyama T, Shitara A, Kondo H, Aoki T, \& Hirono I. Involvement of WSSV-shrimp homologs in WSSV infectivity in kuruma shrimp: Marsupenaeus japonicus. Fish \& Shellfish Immunology 2010; 88:217-226.

[37] Tare M, Duran C, Icaro C, Montelibano J, Tadeo C, Guanzon D, \& Maningas M. Characterization of hemocyanin-like subunits in giant freshwater prawn Macrobrachium rosenbergii. AACL Bioflux 2015; 8(3).

[38] Lazarte J \& Maningas MBB. Targeting essential gene utilizing RNA interference to protect ailing shrimp/prawn industry against WSSV. Resource Enhancement and Sustainable Aquaculture Practices in Southeast Asia Proceedings (2014).

[39] Alenton RR, Kondo H, Hirono I, \& Maningas MBB. Gene silencing of VP9 gene impairs WSSV infectivity on Macrobrachium rosenbergii. Virus Research 2016; 214:65-70. doi:10.1016

[40] Maralit B, Ventolero M, Maningas M, Amar E, \& Santos M. Subtracted transcriptome profile of tiger shrimp (Penaeus monodon) that survived WSSV challenge. Dataset Papers in Science 2014.

[41] Walker P \& Mohan C. Viral disease emergence in shrimp aquaculture: origins, impact and the effectiveness of health management strategies. Reviews in Aquaculture 2009; 1(2):125-154.

[42] Bricknell I \& Dalmo R. The use of immunostimulants in fish larval aquaculture. Fish \& Shellfish Immunology 2005; 19(5):457-472.

[43] Chang C, Chen H, Su M, \& Liao I. Immunomodulation by dietary â-1, 3-glucan in the brooders of the black tiger shrimp Penaeus monodon. Fish \& Shellfish Immunology 2000; 10(6):505-514.

[44] Apines-Amar M \& Amar E. Use of immunostimulants in shrimp culture: An update. Biotechnological Advances in Shrimp Health Management in the Philippines, pp. 45-71. (2015).

[45] Barman D, Nen P, Mandal S, \& Kumar V. Immunostimulants for aquaculture health management. Journal of Marine Science: Research and Development 2013; 3(134):2.
[46] Ringø E. Use of immunostimulants and nucleotides in aquaculture: a review. Journal of Marine Science: Research and Development 2011.

[47] Montero-Rocha A, McIntosh D, Sánchez-Merino $\mathrm{R}$, \& Flores I. Immunostimulation of white shrimp (Litopenaeus vannamei) following dietary administration of Ergosan. Journal of Invertebrate Pathology 2006; 91(3):188-194.

[48] Mills S \& Bone K. Principles of herbal pharmacology. Principles and Practice of Phytotherapy: Modern Herbal Medicine 2000; 22-79.

[49] Citarasu T, Sivaram V, Immanuel G, Rout N, \& Murugan $V$. Influence of selected Indian immunostimulant herbs against white spot syndrome virus (WSSV) infection in black tiger shrimp, Penaeus monodon with reference to haematological, biochemical and immunological changes. Fish \& Shellfish Immunology 2006.

[50] Maningas M, Gonzalez P, Obias M, Pausanos R, Siapno J, Alambra J, \& Abquina E. Immune response of Macrobrachium rosenbergii immersed in hot-water extract of Gracilaria edulis. Philippine Science Letters 2013; 6(2):147-152.

[51] Huynh T, Yeh S, Lin Y, Shyu J, Chen L, \& Chen J. White shrimp Litopenaeus vannamei immersed in seawater containing Sargassum hemiphyllum var. chinense powder and its extract showed increased immunity and resistance against Vibrio alginolyticus and white spot syndrome virus. Fish \& Shellfish Immunology 2011; 31(2):286-293.

[52] Kumar I, Chelladurai G, Veni T, Peeran S, \& Mohanraj J. Medicinal plants as immunostimulants for health management in Indian cat fish. Journal of Coastal Life Medicines 2014; 2(6):426-430.

[53] Harikrishnan R, Kim J, Balasundaram C, Jawahar $S$, \& Heo M. Effect of Magnifera indica kernelenriched feed on immune response of Penaeus indicus against white spot syndrome virus (WSSV). Aquaculture International 2012; 1-12.

[54] Nahavandi R, Amin S, Hafezamini P, \& Javanmard A. Evaluation of Nutritional Genomes Approach for Controlling of Disease in Shrimp Farming. Journal of Animal and Veterinary Advances 2010; 9(20):2613-2619. 
Tare MVR, et al. | Acta Manilana 64 (2016)

[55] Rudtanatip T, Asuvapongpatana $\mathrm{S}$, Withyachumnarnkul B, \& Wongprasert K. Sulfated galactans isolated from the red seaweed Gracilaria fisheri target the envelope proteins of white spot syndrome virus and protect against viral infection in shrimp haemocytes. Journal of General Virology 2014; 95(5):1126-1134.

[56] Subramanian V, Jang Y, Kim D, Kang B, \& Heo V. Dietary effect of Rubus coreanus ethanolic extract on immune gene expression in white leg shrimp, Penaeus vannamei. Fish \& Shellfish Immunology 2013; 35(3):808-814.

[57] Wang S \& Chen J. The protective effect of chitin and chitosan against Vibrio alginolyticus in white shrimp Litopenaeus vannamei. Fish \& Shellfish Immunology 2005; 19(3):191-204.

[58] Fu Y, Hou W, Yeh S, Li C, \& Chen J. The immunostimulatory effects of hot-water extract of Gelidium amansii via immersion, injection and dietary administrations on white shrimp Litopenaeus vannamei and its resistance against Vibrio alginolyticus. Fish \& Shellfish Immunology 2007; 22(6):673-685.

[59] YehS, Lee C, \& Chen J. Administration of hotwater extract of brown seaweed Sargassum duplicatum via immersion and injection enhances the immune resistance of white shrimp Litopenaeus vannamei. Fish \& Shellfish Immunology 2006; 20(3):332-345

[60] Huang $X$, Zhou $H$, \& Zhang $H$. The effect of Sargassum fusiforme polysaccharide extracts on vibriosis resistance and immune activity of the shrimp, Fenneropenaeus chinensis. Fish \& Shellfish Immunology 2006; 20(5):750-757.

[61] ChotigeatW, Tongsupa S, Supamataya K, \& Phongdara A. Effect of fucoidan on disease resistance of black tiger shrimp. Aquaculture 2004; 233(1).

[62] Sung $H$, Yang $Y$, \& Song $Y$. Enhancement of microbicidal activity in the tiger shrimp Penaeus monodon via immunostimulation. Journal of Crustacean Biology 1996; 16(2):278-284.

[63] Suphantharika M, Khunrae P, Thanardkit P, \& Verduyn C. Preparation of spent brewer's yeast $\beta$-glucans with a potential application as an immunostimulant for black tiger shrimp, Penaeus monodon. Bioresource Technology 2003; 88(1):55-60.
[64] Vazquez L, Alpuche J, Maldonado G, Agundis C, Pereyra-Morales A, \& Zenteno E. Review: immunity mechanisms in crustaceans. Innate Immunity 2009; 15(3):179-188.

[65] Cerenius L, Lee B, \& Söderhäll K. The proPOsystem: pros and cons for its role in invertebrate immunity. Trends in Immunology 2008; 29(6):263-271.

[66] Sajeevan T, Philip R, \& Singh I. Dose frequency: a critical factor in the administration of glucan as immunostimulant to Indian white shrimp Fenneropenaeus indicus. Aquaculture 2009; 287(3):248-252.

[67] Urmi K, Mahboob S, Hossain M, Bhusal P, \& Hamid K. Antioxidant Activity and Brine Shrimp Lethality Bioassay of Different Parts of the Plant Calotropis gigantea R. Br. (2012).

[68] Immanuel $G$, Sivagnanavelmurugan $M$, Marudhupandi T, Radhakrishnan S, \& Palavesam A. The effect of fucoidan from brown seaweed Sargassum wightii on WSSV resistance and immune activity in shrimp Penaeus monodon (Fab). Fish \& Shellfish Immunology 2012; 32(4):551-564.

[69] Itami T, Asano M, Tokushige K, Kubono K, Nakagawa A, Takeno N, \& Takahashi Y. Enhancement of disease resistance of kuruma shrimp, Penaeus japonicus, after oral administration of peptidoglycan derived from Bifidobacterium thermophilum. Aquaculture 1998; 164(1):277-288.

[70] Wang V. Effect of probiotics on growth performance and digestive enzyme activity of the shrimpPenaeus vannamei. Aquaculture 20071 269:259-264.

[71] Azad I, Panighari A, Chavali G, Paulpandi S, Mahima $\mathrm{H}$, \& Pitchaiyappan R. Routes of immunostimulation vis-à-vis survival and growth of Penaeus monodon postlarvae. Aquaculture 2005; 248(1):227-234.

[72] Desai U, Achuthankutty C, \& Sreepada R. U.S. Patent No. 6,440,466. (Washington, DC: U.S. Patent and Trademark Office, 2002). 